\title{
Safety of Infliximab in Patients Suffering from Inflammatory Bowel Disease
}

\author{
C. Felley P. Michetti \\ Division of Gastroenterology and Hepatology, University Hospital, Lausanne, Switzerland
}

Tumor necrosis factor- $\alpha$ (TNF- $\alpha)$ is a central cytokine in the inflammatory process associated with Crohn's disease (CD). Infliximab, a chimeric IgG1 antibody directed against soluble and membrane-bound TNF- $\alpha$, has shown efficacy both in luminal and fistulizing CD. It was approved in October 1998 by the US Food and Drug Administration for the treatment of moderate to severe $\mathrm{CD}$ refractory to conventional therapies. It can be used both to induce $[1,2]$ and to maintain remission $[3,4]$.

Among the adverse events associated with infliximab therapy in $\mathrm{CD}$ patients, infections have been reported already in the original study by Targan et al. [1]. In the pivotal ACCENT I maintenance trial [3], serious infections occurred in $4 \%$ of patients. In addition, malignant disorders were reported in $1 \%$ of the patients. Infusion reactions led to discontinuation of infliximab in 12 out of 573 patients. One patient was judged to have developed a lupus-like syndrome.

In a report published in this issue of the journal, Seiderer et al. [5] review the safety of infliximab in 100 consecutive patients $(92 \mathrm{CD}, 7$ ulcerative colitis and 1 indeterminate colitis). Adverse events were observed in 10 patients ( 2 with an acute infusion reaction, 1 with a serum sickness-like reaction, 4 with a bacterial or viral infection, 1 with pancytopenia and 2 with surgical complications). The authors concluded that infliximab appears to be a relatively safe therapeutic option for patients with severe inflammatory bowel disease.
When a larger population of patients was studied, serious adverse events, including deaths, have been observed. The Mayo Clinic reviewed their experience in 500 patients treated with infliximab [6]. These patients received a median of three infusions and had a median follow-up of 17 months. Serious adverse events were observed in $8.6 \%$, of which $6 \%$ were related to infliximab. Acute infusion reactions occurred in $3.8 \%$. Serum sickness-like disease was observed in 19 patients and was attributed to infliximab in 14 (2.8\%). Three patients developed druginduced lupus. Twenty patients had a serious infection and a total of 10 deaths were observed, of which 5 were possibly related to infliximab.

Recently, preliminary data from the TREAT registry have been presented concerning the safety of infliximab in 5,807 patients $(2,850$ having received infliximab and 2,957 not) [7]. This study is possibly more representative of the real safety of infliximab, since only $20 \%$ of the patients were treated in academic centers. On the other hand, since reporting was on a voluntary basis, the study could be susceptible to substantial bias. In total, 11,504 infusions were analyzed with a mean follow-up of 0.9 year. Adverse reactions and serious adverse reactions occurred in 5.4 and $0.16 \%$, respectively. A 10 -fold increase in mortality was observed in patients receiving infliximab and concomitantly treated with steroids (OR 5.8). Serious infections were associated with female sex and current use of steroids or narcotic analgesics. No dif-

\footnotetext{
Dr. C. Felley

Division of Gastroenterology and Hepatology

CHUV-BH10

CH-1011 Lausanne (Switzerland)

Tel. +41213140690, Fax +41213140707, E-Mail christian.felley@hospvd.ch
} 
ference was observed in all the cancers and lymphoma nor any difference in the outcome of pregnancy between patients treated by infliximab or not. Another populationbased study from Stockholm County describes the results of infliximab in 217 patients (191 CD, 22 ulcerative colitis and 4 indeterminate colitis) [8]. The mean number of infliximab infusions was 2.6. Forty-two severe adverse events were observed in 41 patients $(35 \mathrm{CD})$. Eleven of the severe adverse events occurred postoperatively. Two patients died from lymphoma and 2 patients with a severe attack of inflammatory bowel disease died due to sepsis. The mean age in the group with fatal outcome was 62.7 vs. 37.6 years for the whole cohort. It should be noted that other therapies commonly used for severe CD, including steroids, were also associated with severe adverse reactions and deaths [9].

Several reports have now described the association of tuberculosis with the prescription of infliximab [10, 11]. Accordingly, screening for tuberculosis and latent tuberculosis is mandatory before prescribing infliximab [12]. Guidelines request that active or latent tuberculosis is excluded by a chest X-ray and a tuberculin skin test.
Infliximab infusion reactions occur in less than $5 \%$ of infusions. They have been associated with the development of antibodies against infliximab [13]. Concomitant immunosuppressive therapy with azathioprine or methotrexate reduces the immunogenic response to infliximab [14].

Finally, TNF- $\alpha$ antagonists have been shown to be associated with new-onset heart failure or to exacerbate existing disease [15] and should thus be used with caution in patients with symptoms of heart failure.

In summary, despite its acceptable safety profile, the benefit-to-risk ratio of infliximab should be assessed in each case with regards to the severity of the disease and keeping in mind that alternative therapies also expose patients to substantial risks. Caution should be exercised when considering infliximab for use in patients who have chronic or latent infections, mild congestive heart failure, are elderly or are treated concomitantly with steroids. The use of infliximab in ulcerative colitis or indeterminate colitis depends on the results of randomized controlled trials. Long-term efficacy and safety data for infliximab are still unclear, and further follow-up of large cohorts of patients is mandatory.

\section{References}

$>1$ Targan SR, Hanauer SB, van Deventer SJ, Mayer L, Present DH, Braakman T, DeWoody KL, Schaible TF, Rutgeerts PJ: A short-term study of chimeric monoclonal antibody cA 2 to tumor necrosis factor- $\alpha$ for Crohn's disease. Crohn's Disease cA2 Study Group. N Engl J Med 1997;337:1029-1035.

-2 Present DH, Rutgeerts P, Targan S, Hanauer SB, Mayer L, van Hogezand RA, Podolsky DK, Sands BE, Braakman T, DeWoody KL, Schaible TF, van Deventer SJ: Infliximab for the treatment of fistulas in patients with Crohn's disease. N Engl J Med 1999;340:1398-1405.

-3 Hanauer SB, Feagan BG, Lichtenstein GR, Mayer LF, Schreiber S, Colombel JF, Rachmilewitz D, Wolf DC, Olson A, Bao W, Rutgeerts P, Group AIS: Maintenance infliximab for Crohn's disease: The ACCENT I randomised trial. Lancet 2002;359:1541-1549.

4 Sands BE, Anderson FH, Bernstein CN, Chey WY, Feagan BG, Fedorak RN, Kamm MA Korzenik JR, Lashner BA, Onken JE, Rachmilewitz D, Rutgeerts P, Wild G, Wolf DC, Marsters PA, Travers SB, Blank MA, van Deventer $\mathrm{SJ}$ : Infliximab maintenance therapy for fistulizing Crohn's disease. N Engl J Med 2004;350: 876-885.
Seiderer J, Göke B, Ochsenkühn T: Safety aspects of infliximab in inflammatory bowel disease patients. A retrospective cohort study in 100 patients of a German university hospital. Digestion 2004;70:3-9.

6 Colombel JF, Loftus EV Jr, Tremaine WJ, Egan LJ, Harmsen WS, Schleck CD, Zinsmeister AR, Sandborn WJ: The safety profile of infliximab in patients with Crohn's disease: The Mayo Clinic experience in 500 patients. Gastroenterology 2004;126:19-31.

7 Lichtenstein G, Cohen R, Feagan B, Sandborn W, Salzberg B, Chen D, Diamond R: Safety of infliximab in Crohn's disease: Data from the 5,000-patient TREAT registry. Gastroenterology 2004;126:A54.

8 Ljung T, Karlen P, Schmidt D, Hellstrom PM, Lapidus A, Janczewska I, Sjoqvist U, Lofberg $\mathrm{R}$ : Infliximab in inflammatory bowel disease: Clinical outcome in a population-based cohort from Stockholm County. Gut 2004;53:849853.

-9 Yang YX, Lichtenstein GR: Corticosteroids in Crohn's disease. Am J Gastroenterol 2002;97: 803-823.
10 Keane J, Gershon S, Wise RP, Mirabile-Levens E, Kasznica J, Schwieterman WD, Siegel JN, Braun MM: Tuberculosis associated with infliximab, a tumor necrosis factor- $\alpha$-neutralizing agent. N Engl J Med 2001;345:1098-1104.

11 Wagner TE, Huseby ES, Huseby JS: Exacerbation of mycobacterium tuberculosis enteritis masquerading as Crohn's disease after treatment with a tumor necrosis factor- $\alpha$ inhibitor. Am J Med 2002;112:67-69.

12 Long R, Gardam M: Tumour necrosis factor- $\alpha$ inhibitors and the reactivation of latent tuberculosis infection. CMAJ 2003;168:1153-1156.

13 Baert F, Noman M, Vermeire S, Van Assche G, D'Haens G, Carbonez A, Rutgeerts P: Influence of immunogenicity on the long-term efficacy of infliximab in Crohn's disease. $\mathrm{N}$ Engl J Med 2003;348:601-608.

14 Farrell R, Alsahli M, Jeen YT, Falchuk K, Peppercorn M, Michetti P: Intravenous hydrocortisone premedication reduces antibodies to infliximab in Crohn's disease: A randomized controlled trial. Gastroenterology 2003;124: 917-924.

15 Kwon HJ, Cote TR, Cuffe MS, Kramer JM, Braun MM: Case reports of heart failure after therapy with a tumor necrosis factor antagonist. Ann Intern Med 2003;138:807-811. 